\title{
FOLLOWING THE TRACE OF BYRONIC HERO IN YUSHIJ'S AFSANEH
}

\author{
Mohammed Hussein Oroskhan \\ Vali-e-Asr University of Rafsanjan, Iran
}

\begin{abstract}
Romanticism broke the hierarchical chain of thought permeated into the society of human being and indeed initiated a new and unprecedented process of thought. Morse Peckham has coined the term "dynamic organicism" and "static mechanism" to describe and distinguish between these two ways of thoughts. Considering "dynamic organicism" as the prominent way of thought in romantic era, he subcategorized it into positive and negative romanticism to better illustrates the works of different romantic writers. As a result, he considers the concept of Byronic hero as the way of symbolizing the state of negative romanticism. In a parallel way the concept of Byronic hero can be explored through NimaYushij's Afsaneh in the context of Persian modern poetry. In this case, NimaYushij, the father of modern Persian poetry, is believed to have changed the long-establishing way of thinking about poetry by bringing about the same shift of thought as the romantics did. Finally, an attempt is made to prove that Nima's two characters, the lover and Afsaneh, in Afsaneh conveys the same concept of romantic's Byronic hero and spirit respectively.
\end{abstract}

Keywords: Byronic Hero; Negative Romanticism; Dynamic Organicism; Spirit.

\section{Introduction}

NimaYushij (1897-1960), the father of modernist poetry, was born in a small city named Yush near Rasht. Yush is a really beautiful and green village in which Yushij grew up. He really adored living in Yush. However, everything changed when in 1910 he, along with his brother, was sent to Tehran for education. They were enrolled in a Catholic school named Saint Louis. Later in his adulthood, he described his situation in a letter to one of his friend in this way; "finally this place of peace and natural scenery has all of a sudden disappeared. I was separated from my roots I came to this dirty city of Tehran" (Nima Letters, 1984: 105).

His first years in Saint Louis were terrible as he was always in fight with other children and could not concentrate on his lessons due to his upbringing in the wild nature. However, this dull and monotonous situation didn't last forever when a silver lining shone in his life and his rare and extraordinary talent was recognized by a great teacher. "And it was in later time that through the encouragement of an affable and well-behaved teacher, Nezam-Vafa, that I started writing poetry" (ibid, 25). Nezam-Vafa was a French language teacher. Therefore Yushij became acquainted with the French language through his teacher Nezam Vafa. Yushij had a really high opinion of his teacher, "this hermit poet, and so pure, full of painful sensitivity and poetical characteristics, is the one who put poetry in my mouth and led me to this path" (169). Clearly, this opinion shows that Nezam Vafa was really more than a mere French teacher; he indeed became the person whom Yushij dedicated his first major poem, Afsaneh, "I dedicate this to my mentor, although I know that this poem is a worthless gift but he will forgive the mountain people for their simplicity and candor"(38). 
Majid Naficy (1997) in Modernism and Ideology in Persian Literature asserts that "Nezam-Vafa, was deeply in ecstasy with the French Romantic School" (33). Based upon Naficy's assertion, this could be implied that Yushij became acquainted not only with French language but also with the French Romantic School through Nezam-Vafa. However, in this study our aim is not to focus on the common points of Nima's Afsaneh and French Romanticism because in our previous article entitled "NimaYushij's Afsaneh as a Striking Exemplar of the 'Greater Romantic Lyric"', we thoroughly explored Yushij's Afsaneh with respect to French and English Romanticism. As a result, in this paper our attempt is to investigate Yushij's Afsaneh with regard to Morse Peckham's theory of Byronic Hero presented in his series of articles.

\section{Romanticism}

Moreover, this should be noted that in our comparative study of exploring the notion of Byronic hero in Yushij's Afsaneh, we are entirely concentrating on the common points of the concept of Byronic hero and Yushij's Afsaneh. It means that we never try to consider the aspects on which Byron has influenced Yushij but how the concept of Byronic hero is developed on Yushij's Afsaneh. Because Byronic hero has a pluralistic nature and Lord Byron is not its sole creator. Many factors can be believed to contribute to its development. As Peter L. Thorslev, Jr (1965) asserts in The Byronic Hero: Types and Prototypes that:

Byronic hero is unique, in one sense, in the powerful fusion of disparate elements into a single commanding image; but he did not spring by a miracle of parthenogenesis from Byron's mind; he is to a large extent a product of a Romantic heroic tradition which was a halfcentury old before he appeared (12).

In this regard, it is most necessary to first acquire a notion of romanticism and then narrow down its definition to Morse Peckham's theory of Byronic hero. Throughout the last two centuries, defining the concept of romanticism has caused romantic scholars to wander around it in a daze. And mostly, their search failed in reaching a basic definition. In this regard, Edward F. Kravitt (1992) has been aware of the underlying reason for such a failure. He believes that the scholars of romanticism have never launched to search for the essence of romanticism and they have always been amused with "romanticism's outward appearance" (93).

In this respect, the romantic scholars are seriously misled about understanding the concept of romanticism due to their selection of improper filed of investigation. They should focus on the "romantic artist" (ibid, 93) instead of portraying the "romanticism's outward appearance" (93). Of the subject of considering romanticism's outward appearance, Arthur O. Lovejoy has conducted a comprehensive review of romantic scholar's definition of the romanticism. He has listed a number of romantic scholars such as Professor Ker, Mr. Gosse, Mr. F. Y. Eccles, Mr. Geoffrey Scott, and Mr. Paul More. Then he mentions that these scholars have provided different notion of romanticism such as an inherent tendency toward nature, a fascination with the past or such negative view as considering the romantic system of ideas as the direct source of the realistic error. And in this case, Lovejoy seems to go along the right path when he concludes that "the romantic ideas are in large part heterogeneous, logically independent, and sometimes essentially antithetic to one another in their implications"(Lovejoy, 1924: 261).

In this case, Lovejoy is not fully aware of his improper field of investigation. This means Lovejoy should have focused on internal (the poet's mind) aspects instead of focusing on external (romanticism's outward appearance) aspects. In this regard, critics 
like Lovejoy can be blamed for neglecting this significant shift occurred in romanticism. However, Kravitthas taken into account this shift of thought presented by romanticism therefore he presented the notion of "traditional definition of romanticism"(1992, 93) to describe those perspectives like Lovejoy which have neglected this significant shift of thought and have centered their studies on "romanticism's outward appearance" (ibid, 93). Then he proposes that this significant shift has caused the poet to experience a sense of alienation and isolation (99) and then he provides us with a new platform for approaching the concept of romanticism. Unfortunately, he never elaborated on this theory of isolation and alienation and just distinguishes it as the unique method of understanding the concept of romanticism.

\section{Morse Peckham's Theory of Dynamic Organicism}

Nevertheless, Morse Peckham fully clarified this new and different outlook in a series of articles. Peckham came to understand that an unprecedented way of thinking occurred in nineteenth-century Europe, an approach in poetry that had never happened before in the history of human being. Interestingly, Peckham came to this realization by juxtaposing two well-known romantic critics, Rene Welleck (1949) and Arthur O. Lovejoy (1924). Peckham mentions that that Rene Wellektried to evade Lovejoy's skepticism by establishing three main criteria of "the same conception of nature and its relation to man, and basically the same poetic style, with a use of imagery, symbolism, and myth which is clearly distinct from that of eighteenth-century neoclassicism" (Wellek, 1947: 147). Moreover, Peckham added that though these criteria can be used to explore poets like Samuel Taylor Coleridge and William Wordsworth, Lord Byron has always been considered as a mismatch to Wellek's viewpoint.

In this respect, Peckham embarked on writing several articles to clarify this point and indeed by clarifying the realm of Lord Byron, he responded to the shift occurred in romantic thought. First he drew a line between the previous attempts of defining romanticism and his attempt by determining the problem of romanticism. "The problem of understanding Romanticism is the problem of locating with accuracy its problem (Peckham On Romanticism, 1970: 217)". Then he describes this problem as "a crisis in European culture (which) appears to be a widely accepted notion"(ibid, 217).

In his view, the romantics responded to this crisis in thought by adopting the role of cultural and social isolation which became "the psychological strategy by which the Romantics met the crisis" (217). In fact Peckham refers to a change in the way mind works which was totally unprecedented and also had a big effect on the methods and objects of European arts. Moreover, he makes a distinction between two dynamic and static mechanisms by saying that "the shift in European thought was a shift from conceiving the cosmos as a static mechanism to conceiving it as a dynamic organism" (Peckham Toward a Theory, 1951: 9). For Peckham, static mechanism is established by a central principle in which everything is arranged so well that it works like a machine. "Static mechanism is a mechanism in that the universe is a perfectly running machine, a watch usually" (ibid, 9). Moreover if any flaw or weak point is recognized in this system; that cannot be considered as a malfunction of the system whereas we are not able to truly understand it. Another essential factor regarding this system is that, if one aims to succeed in such a system he or she needs to develop his or her ability to perfectly match with the system otherwise that person will never have any chance of success. This means that for each person, regardless 
of his status in the society, there is just one absolute value to be achieved otherwise he is doomed to failure. In fact, Peckham asserts that "the success of any individual thing according to its ability to fit into the workings of the machine" (10).

However this grand system of thought fell apart in the late enlightenment due to its internal inconsistencies. Therefore the finer minds of the century decided to search for a new system of thought which could explain to them the nature of reality. Peckham has labeled the term organicism for this new way of thought and deems the quality of being as the prominent factor of this new system. "The new metaphor is not a machine; it is an organism... Now the first quality of an organism is that it is not something made, it is something being made or growing (10)". Moreover, the parts of this new system are not fit together in a hierarchical way whereas they are match together in a harmonious way and instead of being like a flawless machine; it is more like a living organicism in which each part is interwoven together. Therefore, the organicism develops intuitively and organically, a "change becomes a positive value, not a negative value"(10) because "Perfection ceases to be a positive value. Imperfection becomes a positive value"(11). Therefore, it means when a small change is added to the organicism the "the fundamental character of the universe itself changes" (11). The consequent outcome of such viewpoint is that any work of art becomes unique in its nature because it grows its own aesthetic laws out of the previous organicism due to its own developing nature.

Henceforth, Peckham aims at working with his concept of dynamic organicism as opposed to the previously established concept of static mechanism. He later adds that for clearly illustrating this concept, it is necessary to provide a distinction between the appearance and disappearance of dynamic organicism. Therefore, Peckham coins the term positive romanticism and negative romanticism to gain this purpose. "To this term I should now like to add 'positive romanticism', as a term useful in describing men and ideas and works of art in which dynamic organicism appears, whether it be incomplete or fully developed" (14). Then Peckham suggests that in the case of Byron one cannot understand it in terms of the appearance of dynamic organicism therefore he introduces this new term of 'negative romanticism' to solve the problem of understanding Byron. And he briefly defines the concept of negative romanticism as "the expression of the attitudes, the feelings, and the ideas of a man who has left static mechanism but has not yet arrived at a reintegration of his thought and art in terms of dynamic organicism"(15).

For clarifying this new term, Peckham cites some examples from the earlier romantic writers like Coleridge and Wordsworth but not to unify them with Byron. He mentions Coleridge's The Ancient Mariner and Wordsworth's The Prelude to show that these two writers could change and developed out of their preliminary states but Byron could never do that and stayed in the state of negative romanticism (16). This means that Byron could not generate out of the static mechanism and got involved with dynamic organicism and experiences the spiritual rebirth. Because in Peckham's view:

A man moves from a trust in the universe to a period of doubt and despair of any meaning in the universe, and then to a re-affirmation of faith in cosmic meaning and goodness, or at least meaning. The transition from the first stage to the second, we may call spiritual death; that from the second to the third, we may call spiritual rebirth (16).

\section{Morse Peckham's Definition of Byronic Hero}

Indeed, Peckham noticed an unprecedented phenomenon in the trait of romanticism so as to explain Byron's works. And he defined the concept of negative romanticism in a nutshell. But in another article entitled "The Dilemma of a Century: The Four Stages of 
Romanticism" he fully elaborated on this concept and categorized not only Byronism but also gave a more general view of Romanticism. He believed that when a connection is established between the mind and the world, a consequent role is also appeared by the men. This role has taken different shape up to the time of romantics. As an example, during the enlightenment, roles were like "modes of behavior derived from the natural world, or dictated by a divine being, or inherent in man's relation to his world" $(2009,9)$ but during the time of romantics, a new social role was developed due to the profound cultural changes of the time "a new social role is in itself almost sufficient evidence that the nineteenth century was experiencing a cultural earthquake, a convulsion at the profoundest levels of being" (ibid, 8). For the romantics the essence of self was so important that they decided to create an anti-role just for the sake of highlighting the role of self. Because they believed that only the self can comprehend the quality of experience.

Therefore, in the mind of the romantics, roles were conceived up as the carrier of human's intension with the aim of shaping the external world; "Roles were seen as something that man imposes on the world, something therefore, with the character of a mask" (9). The romantics put the concept of mask aside with the social role taken by the men because in their view, mask is the necessary force of deriving men upward but not the sole quality to realize the essence of experience. For the romantics, such masks created the problem of forgetting the self as the self is so cloaked in different masks that no one feels its existence; therefore, the romantics decided to create an anti-role which could be distinguished among all of these interwoven roles so as to show the true self. Peckham describes this anti-role as "a role that was different from all other roles in that it could not be integrated into the social structure of interlocking roles"(9).

Upon this path, the romantics were left unaided due to their change of view of the French revolution, as it was redirected from "Utopian liberation to tyrannous oppression" (10). Suddenly, the belief in correcting the outer world with a revolution gave its place to a world in which "the individual no longer had a source for his sense of identity and a ground for his desire for order and structure" (11). This change of view affected the romantics greatly that they were signed to experience "a sense of profound isolation within the world and an equally terrifying alienation from society. These two experiences, metaphysical isolation and social alienation were the distinguishing signs of the Romantic, and they are to this day" (11). In this respect, Peckham believes that one way of expressing the utter sense of loss is through the Byronic Hero as "it is a way of symbolizing precisely that utter loss of meaning and value which so many people experienced-and continue to experiencewhen the Enlightenment collapsed" (Peckham Dilemma of a century, 2009: 11).

\section{Investigating the Concept of Byronic Hero in Yushij's Afsaneh}

In our Persian context, Yushij also took the same direction. His political views of the time were heavily leaned toward a revolutionary force named Nehzat-e Jangal (Forest movement). This revolutionary force dates back to the time before Reza Shah (18781944) took the power and became the first Shah of Pahlavi Dynasty. At that time different revolutionary forces were active in Iran. Nehzat-e Jangal was one of these forces located in Northern part of Iran where Yushij was born. The leader of this group was Mirza Kuchek Khan Jangali. However the movement was demolished when its connection with the Bolshevik peasant in Caucasia was severed because Bolshevik power decided to change their policy towards Iran and support Reza Khan to seize the throne. As a result, the unity of the Jangali movement broke and Mirza died due to frostbite in one of the 
Alborz Mountains named Talesh in 1921. Naficy believes that "Yushij's views on social reforms and revolution in these times reflect the ideas of Jangali movement"(1997:100).

This event depressed Yushij to the extent that he decided to take a revenge action himself. And he expresses his emotion in a letter to his brother in this away.

After this has occurred to me, I want to make a new life for myself: Living in the forest and participating in the struggle. In a few days, I will leave this area. I will go where I can provide for this new life. If I succeed, a new uprising created by me will emerge in this part of Mount Alborz and I will display the originality of the brave warriors in this mountain (NimaLetters, 1984: 15).

However, Nima himself knows that he is not the man of battle and utterly expresses his incompetency in another letter to his brother; "what can I do my dear, I am not Comrade Lenin, I am not Karl Marx. My heart is trembling in an endless vibration and altogether I am different from all of them" (ibid: 147).

The other incident happened to Yushij before writing Afsaneh is regarding his love stories. Yushij fell in love with a beautiful girl named Helena when he was in Tehran however Helena never returns Yushij's affection and rejects him. Then Yushij decides to go back to his native place to forget his love story. Interestingly, amidst the nature, he again falls in love with a pretty girl named Safura. Filled with the bitterness of his previous beloved, Nima gets so tempted to marry Safura nonetheless he fails miserably and the image of this failure stays with Yushij to the extent that Abul-Qasem Jannati Atai specifically related Yushij's Afsaneh to this sad tale of unrequited love. "Inspired by Safura's love and filled with the impact of its failure, he created the eternal poem Afsaneh" (Jannati, 1955: 21).Surely, it is not wise to relate Afsaneh solely to Yushij's unrequited love because it is a highly philosophical poem as it will be discussed in the rest of this paper. However,

It was felt necessary to mention these two points regarding Yushij's life to illustrate that Yushij's life can also be proved to be situated in a romantic context. In this sense, Yushij built his trust in the universe by strongly relying on Jangali movement however this movement was ruined. As a result, this phenomenon isolated Yushij from his idea of participating in social movement to save the world. Then Yushij heavily relied on his inner feelings and again he became dejected and alienated from within. At this moment, this could be implied that Yushijwas experiencing a spiritual death from which he never recovered. Indeed, Yushij like the romantics decided to form different anti-roles to symbolize his sense of isolation from the external world and alienation from within. In this respect, Peckham believes that one way of expressing the utter sense of loss is through the Byronic Hero as "it is a way of symbolizing precisely that utter loss of meaning and value which so many people experienced-and continue to experience-when the Enlightenment collapsed" (Peckham Dilemma of a century, 2009:11). Peckham traces the development of the Byronic Hero from pre-Enlightenment Christianity to Enlightenment and how this type of romantic hero became a symbolized notion during the romantic age. Moreover, he suggests that the concept of the Byronic hero is flowered out of the negative romanticism because it has an instinct of negation in itself. His inner feeling cannot tolerate the order of the society and as he cannot achieve an acceptable order for himself, he just relies on his inner self for understanding the outside world.

As one can see, during the romantic era any connection between the subject (the mind) and the object (external world) was severed. Then an unbridgeable gap appeared between the subject and the object. The consequent result of such gap has been the 
romantic's symbolization of anti-role called Byronic hero. In this respect, the romantics focused on the inner tension between the subject and the object. Then they tried to create a specific concept for understanding this new viewpoint of reality. "Spirit' is the term many Romantics used for the interpretational tension from Subject to Object, and reality, therefore, is the history of Spirit"(ibid: 16).

The main reason that the romantics created the concept of 'spirit' for dealing with reality was to distinguish the new presentation of reality with the previous notion of reality existed in the enlightenment era. Because during the previous era, "the Enlightenment placed perceptions by putting them into the frame of unchanging nature; Romanticism places them by putting them into the frame of historical process. Reality is neither space nor time; it is the process of history"(16). Surely, this new way of thinking has compelled Peckham to call the period of romanticism as "the profoundest cultural transformation in human history since the invention of the city"(16).

Referring to Yushij's Afsaneh, this could be noticed that it is in the form of a dramatic dialogue between two characters of Afsaneh and the lover. Approaching Afsaneh with respect to Peckham's theory of Byronic hero, we aim at proving that the lover plays the role of Byroinc hero and Afsaneh can be deemed as the created concept of 'spirit' for dealing with the elusive nature of reality. Indeed through the occurrence of an unrestrained conversation between these two characters, Yushij aims at revealing the elusive nature of reality. As he himself mentions in his preface to this poem that

I call the structure of my Afsaneh dramatic, and I know that no other name will be adequate for it. That is because this is basically the type of structure that can be used in the composition of dramas, in enabling the personages of the story to converse freely (Yushij, 1992: 36).

This can be shown that Yushij's unprecedented way of writing poem is not accidental and he intends to draw specific meaning from the occurrence of this conversation. Two years after the composition of the poem, in a letter to an unknown addressee, Yushij complains that his readers have failed to understand the enigma conveyed in Afsaneh and the secret that distinguishes his modernist poem from the Persian classics (KarimiHakkak, 2004: 176). The secret that Yushij called in one of his letter is exactly the shift that Peckham described happening in European art during romanticism. Peckham believed that conceiving a work of art through dynamic organicism proves that the work of art has no fixed or static meaning but changes with the observer in a relation between the two which is both dialectical, or dynamic, and organic. And Yushij has created this relationship between the lover and Afsaneh.

As it was mentioned, Afsaneh can be deemed as the supposed player of the role of the romantic's spirit because by investigating the poem, this could be shown that Afsaneh has taken many roles. Interestingly, the word Afsanehin Persian means "a fairy tale for the purpose of bringing about a moral lesson" (Masih, 2013: 165). It seems that even its denotative meaning conveys the role of romantic's spirit. Regarding the poem and in its beginning, Afsaneh addresses a madman who seems to be the lover, "In the somber night, a madman who/Has committed his heart to a fleeting hue/Is sitting in a clod, quiet vale/Like the stem of a withered plant/He begins a sorrowful tale (Nima, 1992: 39)". As it becomes clear, Afsaneh is talking to the lover who has committed himself to a fleeting hue which can show the instability of an absolute value. Amazingly, in continuing this section, Afsaneh exchange his role from an addressee to the personification of the lover's heart. This point needs to be added that the heart should be considered as the lover's central value in this poem, "Oh my heart, my heart, my heart!/Miserable, hurt, my dear 
partner/With all goodness, value, and claim/What did I gain from you in the end/But a tear on the face of gloom? (ibid: 38-39)". Now Afsaneh, in the place of the lover, is mourning over the situation into which the lover has been deluded. However in another part Afsanehintroduces him/herself as the heart of the lover, "Me, I am the fruit of life/Me, I am the light of a word/I, Afsaneh, am the lover's heart./If there is a body and soul, it is me, me./I am the flower of love and born of tears (47)".Now, Afsaneh puts himself as the essential element of the lover's world. Afsaneh's role playing continues as a dear beloved with whom many lovers had fallen in love:

$\mathrm{Me}$, I was once a girl

Me, I was a beloved sweetheart

My eyes were full of deception

$\mathrm{Me}$, I was a sorceress

I came and sat on a tomb

A harp playing in one hand

In the other hand a cup of wine

Even before turning up, I got tipsy

Because of my black eyes, night is weeping

Drop by drop tears full of blood (44).

Changing from a lover's heart to a dear beloved can prove the elusive nature of Afsaneh. Nonetheless, this is not the end as Afsaneh personifies him/herself as the ideal love in a platonic or abstract sense,

Oh, lover! I am that unknown person

I am that sound which comes from the heart

I am the image of the dead of the world

I am one moment which is over like a thunderbolt

I am a warm drop from a wet eye (55).

Even Afsaneh is described as a being existed from the beginning of the time into a state of an eternity,

When my mother took me from my cradle,

She was telling me your story

She told me about your face

My eyes went to sleep in your rapture

I became unconscious and spellbound

Slowly when I started walking

Going in for childish games

Whenever night would fall

Near the spring and river

I heard your voice from within (41-42).

On the contrary, in one part of the poem Afsaneh compares him/herself with Satan banished from heaven who wanders around the world and seduces people's hearts, "I am hidden from listless hearts/Me, a fugitive from the heavens/I have lost everything in heaven and earth/Whatever I am, I am with lovers/I am whatever you say and whatever you want (43)". Even Afsaneh's sex is not clear. In the above example Afsaneh was described as a beautiful girl but Afsaneh appears in both sexes:

A cold wind was howling outside

A fire was burning inside the cabin

A girl came in all of the sudden

Who was saying, as she was knocking on her head

Oh, my heart, my heart, my heart!

She sighed broken heartedly...

She fell on her mother's bosom and felt cold

Do you know how such a heartbroken girl 
Became so down and out

I am the love which makes you mortal, I am the love! (46-47).

As a result, the creation of Afsaneh can be considered as Yushij's method of dealing with reality. Afsaneh takes different roles at different times through the poem and this exactly shows the elusive nature of reality. For romantics, reality and identity are not static throughout the time whereas it changes and takes different forms. In Yushij's view, Afsaneh is the only way of dealing with reality because it can never be settled. Afsaneh can prove that no ultimate reality ever exists. Even when the lover puts Afsaneh in every possible situation to determine its nature but all to no avail and he/she is barely recognized:

Are you my destiny Afsaneh?

You who is disheveled and sorrowful

Or are you my heart, bound with anxiety

Or are you two tear-stained eyes

Or the devil chased out of every place.

Are you my pre-occupied heart

You who are so unrecognized and anonymous

Or are you my nature that you didn't search

After splendor, fame and name?

Or are you fortune, you who escape me so?

Everybody has driven you away

Not knowing that you are eternal

Who are you? Oh you cast out of all places

For me you have been a companion

Are you tear-drop? Are you sorrow?(44-45).

This part of the poem is so revealing not in the case of the nature of Afsaneh whereas it shows how the lover, our supposed Byronic hero, is left desolate in this world due to his ever searching of reality. Indeed for the lover, Afsaneh is the embodiment of the illusive nature of reality which has bewildered him for a long time. The lover after his futile attempt to recognize the nature of reality and achieve a stable goal considers himself not only alienated from within but also isolated from the society. He feels to be situated in a godless universe in which there is no specific principle to rely on. Therefore, in the climatic part of the poem the lover addresses one of the greatest Persian poets and reproaches him for relying on an absolute truth:

O Hafez! What lie and deceit in this

Spoken by the tongue of the wine, the goblet, and the cup-bearers

Though you drove on to eternity, I will not believe

That you fall for that which remains

I am in love with that which moves on

I am amazed! Who are you and I?

And on what seasoned wine are we drunk

We have broken so many bonds

Yet we escaped not the snare of an illusion (65).

This is the most important part of the poem because the lover has named Hafez (1325-1390) who is one of greatest classical Persian poet. Probably, if the lover praised Hafez, it would never attract our attention because Hafez's poems are undoubtedly the best of its kinds throughout the whole Persian literary history. But what has happened to Yushij's the lover that he is accusing Hafez of lying and deceit? In fact, the lover is accusing Hafez regarding one perspective. He never says his poems are of no value or says that they are talking of nonsense whereas he is accusing Hafez of neglecting the dynamic structure of the world. The lover believes that nothing in this world is static and 
the true substance of this world is always changing. That is why he says "I am in love with that which moves on"(65).

In lover's view, the absolute truth of the world is not static and it always changes through different situations. The lover says to Hafez that you have "broken so many bonds" but you are still unable to "escape the snare of an illusion"(65). Lover believes that no one can truly understand this world and find the absolute truth of it. And this is exactly what Peckham has explained when mentioned the concept of 'dynamic organicism' as the basic romantic's foundation. It was discussed previously that the romantics put the concept of mask aside with the social role taken by the men because in their view mask is the necessary force of deriving men upward but not the sole quality to realize the essence of experience. This is exactly what lover has in his mind when he tries to refer to Hafez's poems. Hafez has hidden himself or the absolute truth behind his created mask which is his way of talking about "the wine, the goblet, and the cup-bearers"(65). In this case, Yushij through the lover is urging not only himself but also other poets to break themselves out of these lies and deceits.

One side effect could be derived from this perspective. Can the creation of the concept of 'spirit', which has the force to compel the men toward a transcendental value, help the world to get out of the chaos or not? The answer cannot be affirmative because it has only saved the self and the world is still in consistent chaos. The only silver lining is the possible hope for the self to be entertained. Moreover, Peckham considers the creation of Romantic hero as the only advantage as "the world, wholly of value, turned once again into a meaningless chaos, but preserved the Self and gave the Self's drive for meaning, order, value, and identity a divine authority. This is the heroic, world-redemptive stage of Romanticism"(PeckhamThe Dilemma of a Century, 2009:19).

\section{Conclusion}

It means that the romantic's Byronic hero can never achieve a defined set of value from the existent society because in his view such a society is doomed to failure. Then Peckham believes that the only thing, the Byronic hero can do is to "imagines himself as creating a model, or paradigm, for the future action of mankind"(ibid). In the same situation, Yushij's Byronic hero (the lover) takes the role of a transcendental Byronic hero as he denies the existent of any fixed set of principle in the world. Therefore, at the end of the poem Yushij's hero (the lover) invites other people to joins him to mourn over such a situation, "Oh come forth from this narrow vale/For it is the Shepard's best resting place/ For no one knows the way here/So here, where everything is alone/We may sing together in our melancholy (Yushij, 1992: 71).

The lover longs for a place which is deprived of having any connection with the external world. In his view, nothing can have any value in this world therefore the Shepard should avoid chasing his herd (the nature of reality) and be settled in a "narrow value"(ibid: 71 ) because in this place "everything is alone"(71). It is really important that Yushij has used "everything" not "everyone" for this part. In this case, this could be implied that he is referring to the whole system of the world in which every part is now fallen apart because the central value of this world has been demolished. And the only thing, the lover aims to do is to collect everybody around himself and sing together which means to woo over the situation. Thus Yushij's Afsanehnot only initiated the modern Persian poetry but also opened up a new way of thinking in Persian literary history. 


\section{References}

Jannati 'Ata'I, Abu'l-Qasem. (1955). Nima Yushij: Works and Life. Tehran: Bongah-e Matbu'ati-ye Safi 'Alishah.

Karimi-Hakkak, A. Talattof, K. (Eds.). (2004). Essays On Nima Yushij: Animating Modernism In Persian Poetry. Boston: Brill Press.

Kravitt, Edward F. (1992). "Romanticism Today”, The Musical Quarterly, Vol. 76, No. 1, pp. 93-109.

Lovejoy, Arthur, $O$ (1924). “On the Discrimination of Romanticism.” PMLA, Vol. 39, No. 2, pp. 229-253,

Masih, Heiva (2013). A Dictionary of Modern Persian Poetry: Nima Yushij. Tehran: Doostan,

Naficy, Majid (1997). Modernism and Ideology in Persian Literature: a Return to Nature in the Poetry of Nima Yushij. Maryland: University Press of America.

Oroskhan, M. Hussein and Zohdi, Esmaeil (2016). "Nima Yushij's 'Afsaneh' as a Striking Exemplar of the 'Greater Romantic Lyric' .International Letters of Social and Humanistic Sciences, Vol. 66, pp. 23-30, Feb.

Peckham Morse (1970). “On Romanticism: Introduction.” Studies in Romanticism. Vol. 9, No. 4, The Concept of Romanticism, pp. 217-224.

Peckham Morse (1977). "The Infinitude of Pluralism." Critical Inquiry. Vol. 3, No. 4, pp. 803-816.

Peckham Morse (1949). "The Concept of 'Romanticism' in Literary History II. The Unity of European Romanticism”.Comparative Literature. Vol. 1, No. 2. pp. 147-172.

Peckham Morse (1951), “Toward a Theory of Romanticism”.PMLA.Vol. 66, No. 2. pp. 5-23.

Peckham Morse (1961). "Toward a Theory of Romanticism: II. Reconsiderations.” Studies in Romanticism. Vol. 1, No. 1, pp. 1-8.

Peckham Morse (2009),"The Dilemma of a Century: The Four Stages of Romanticism." Esssays in Romanticism. Vol. 17, No. 1. pp. 7-26.

Thorslev, Jr, Peter L. (1965). The Byronic Hero: The Types and Prototypes. United States: Lund Press, Inc..

Prawer, S. S. (1973). Comparative Literary Studies, Harper and Row Publishers, Inc.

Wellek, Rene (1949). "The Concept of 'Romanticism' in Literary History I. The Term 'Romantic' and Its Derivatives." Comparative Literature. Vol. 1, No. 1. pp. 1-23

Yushij, Nima (1992). Majmu'e-ye Kamel-e Ash'ar Nima Yushij: Farsi va Tabari. Tehran: Negah Publication.

Yushij, Nima (1984). Nameha-ye Nima Yushij, Sirus Tahbaz, ed. Tehran: Nashr-e abi. 